\title{
S.A.A.F. IN KOHEA
}

\section{M. Moore*}

\section{Sixty-four Days in Korea 2 Squadron SAAF: 22 April 1951 - 24 June 1951}

On 23 June 1951 Yakov Malik, Head of the Soviet Delegation to the United Nations, hinted at the possibility of a cease fire in Korea.' The attainment of the revised political objectives of the United Nations was in sight. The Communists were soon to approach the conference table. The use of force had become less profitable to them than negotiation. Prior to this development the war had been in progress for twelve months. The two months preceding Malik's peace approach are of interest in the general history of the war; and in particular, they provide an interesting insight into the role of 2 Squadron, SAAF, its achievements and its problems.

\section{The Ground Situation}

With regard to the ground situation the sixty-four days prior to 24 June 1951 can be divided into two periods: 22 April to 19 May, during which the UN forces successfully resisted the 'Fifth Phase Offensive' of the combined Chinese and North Korean Communist Forces; and 20 May to 24 June, during which the UN forces launched an offensive of their own which was to lead to the stabilization of a Main Line of Resistance (MLR), for the most part just north of the 38th parallel. This Main Line of Resistance was to remain virtually static until the end of the war. (Map 1)

By 21 April 1951 the UN forces had established themselves along the Utah and Kansas Phase lines after a successful offensive? On the night of 22 April 1951 the Communist Forces attacked in strength against the United States I and IX Corps in an attempt to recapture Seoul. ${ }^{3}$ Although they failed to gain this prestige objective, by 30 April 1951 General Van Fleet, who had taken over command from General Ridgway on 11 April 1951 when the latter had been appointed to succeed General MacArthur, was forced to withdraw to the No-name line. ${ }^{4}$ The Communist offensive then came to a halt. General Van Fleet immediately replied with one of his own, designed to deny the enemy the opportunity to build up for a new offensive, by threatening the enemy supply route in the Hwachon area and in the so-called 'Iron
Triangle'. The 38th parallel was declared to be of no tactical significance and a policy of hot pursuit over this artificial boundary was proclaimed. ${ }^{5}$ The United Nations' advance was successful although slowed by rain on 27-28 May 1951. The retreating enemy ground forces, compelled to move during the day, found themselves exposed to attack from the air. By the end of May the UN forces had re-established themselves along the Kansas line. Here they consolidated their position by stringing barbed wire, clearing fields of fire, laying mines, constructing shelters and plotting artillery concentrations. The United Nations Commander-inChief (UNCINC), General Ridgway, then authorized local advances to gain more favourable ground for defence. Accordingly General Van Fleet launched Operation Piledriver on 1 June 1951, which was to bring the US I and IX Corps to the Wyoming line by 15 June 1951. During this advance they encountered heavy enemy resistance organized in depth, as they approached the base of the 'Iron Triangle'. ${ }^{6}$

\section{The Air Situation}

The war in the air during this period was characterized by two features; the initiation of an intensified interdiction campaign by the Far East Air Forces (FEAF) into which SAAF, ROKAF and RAAF elements had been incorporated, and the implementation of a revised air war plan by the Chinese Communist Air Force (CCAF) in midJune. The FEAF interdiction campaign was named 'Operation Strangle' and had as its objective the cutting off of the MLR from the sources of supply in North Korea and Manchuria. A strip of territory stretching east-west across Korea between the parallels $38^{\circ} 15^{\prime}$ and $39^{\circ} 15^{\prime}$ was divided into three interdiction zones, a zone being allocated to each of the 5th Air Force, the Navy and the 1st Marine Air Wing. The enemy road and rail systems were placed under 24-hour

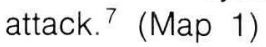

The revised air war plan of the CCAF was thought by FEAF intelligence officers to have been the result of a conference held in Mukden between CCF officers and their Soviet advisers, possibly on 10 May 1951. At this conference the recent failure of their ground offensive was attributed to the CCAF's failure to gain air superiority over 
Korea. In an attempt to rectify this situation the following steps were decided upon:

a. New 'International Communist Volunteer Air Force' personnel would assist the CCAF.

b. Under cover of MIG-15's flown by the best available pilots, the efforts to repair the North Korean airfields would be redoubled.

c. As soon as the North Korean airfields could take light aircraft nuisance raids would be launched against the south.

d. Ilyushin ground attack aircraft, with crews trained in Manchuria by Russian advisers, would be brought forward to support the CCF ground forces in a new offensive. ${ }^{8}$

\section{Squadron's Contribution}

In common with other fighter-bomber squadrons of the 5th Air Force, 2 Squadron SAAF was very much involved in these events. For the most part, air and ground crews of the Squadron were occupied with what amounted to plain hard work. The bulk of the FEAF fighter-bomber effort was devoted to the interdiction missions. As the need arose the fighter-bombers were also sent on close support, rescue and escort missions, sometimes being diverted while en route to pre-briefed interdiction targets. A breakdown of the 1130 combat sorties flown by 2 Squadron from 22 April 1951 to 24 June 1951 inclusive, yields the following percentages:

$\begin{array}{ll}\text { interdiction } & -84,4 \% \\ \text { close support } & -8,4 \% \\ \text { rescue } & -3,6 \% \\ \text { counter-air } & -3,6 \% \\ \text { (airfields) } & \\ & \\ & 100 \%\end{array}$

The squadron's interdiction effort was concentrated against the Main Supply Route (MSR) with the targets being the road and the railway line between Pyongyang, Sariwon, Kaesong and the MLR. Target selection sought the destruction of the communication routes at points difficult to repair or by-pass. Such points were bridges, railway tunnels, cuttings, marshalling yards and routes built up through damp ground such as rice paddies. Supply dumps and troops concentrations en route to the front also enjoyed the attention of the 'Flying Cheetahs'. The close support strikes were mainly in support of the US I Corps in the Western Sector. From the middle of June, 2 Squadron F-51 Mustangs were also called upon to take part in the campaign against the North Korean airfields. This was essentially a counter-air campaign. (Map 3)

\section{Armament}

The standard armament per aircraft against road and railway targets at this time was two $500 \mathrm{lb}$ $(227,3 \mathrm{~kg})$ G.P. bombs, six 5 inch $(127 \mathrm{~mm})$ high velocity aircraft rockets (HVAR) and a maximum load of ,50 ammunition. For attacks on supply areas and for close support missions the G.P. bombs were usually replaced with two 110 gallon $(416,35$ litre) drop tanks filled with napalm and fused with modified white phosphorous grenades. On occasion, four aircraft missions consisted of two aircraft armed with napalm and two armed with G.P. bombs. After the primary target had been bombed with either G.P. or napalm bombs the secondary ordnance was available for targets of opportunity. This secondary ordnance sometimes proved useful when an interdiction mission was diverted by the Joint Operations Centre (JOC) to render close support to the ground forces.

Aircraft attacking the airfields used the $500 \mathrm{lb}$ bombs to pothole the runways, and V.T. fused bombs and rockets for flak suppression. The use of proximity fuses was made possible by the development of an L-bracket which prevented the ordnance being carried on the external wing racks of the fighter-bombers from arming prematurely. ${ }^{10}$ The bombs could now be dropped safely from high above the bursting flak, to explode at an altitude where they caused optimum damage. Bombs with six hour delayed fuses were also placed on the airfield runways during the last raid of the day against the North Korean airfields in order to harass the repair crews operating under cover of darkness.

\section{Squadron Airfields}

On 23 April 1951, 2 Sqn missions took-off from $\mathrm{K}-9$ airfield and landed at $\mathrm{K}-10$ on their return. ${ }^{11}$ The Squadron had been operating from K-9 since 25 March 1951 under the operational control of 35 Fighter-Interceptor Wing, while their normal base at $\mathrm{K}-10$ was being rebuilt. At $\mathrm{K}-10$ they once more functioned under the operational control of 18 Fighter-Bomber Wing. ${ }^{12}$ On their return to K-10 the members of the Squadron found all facilities greatly improved. The improvements were described by the 2 Sqn diarist as being '. . . equivalent to any permanent air station in the Union. ${ }^{13}$ The great disadvantage of $\mathrm{K}-10$ was its distance from the front-line, but this was rectified when the 
aircraft of 18 Fighter-Bomber Wing were instructed to re-arm and re-fuel at the forward airfield K-13, $280 \mathrm{~km}$ north of $\mathrm{K}-10$ as from 2 May $1951 .{ }^{14}$ The three squadrons of the wing, 67 Sqn USAF, 12 Sqn USAF and 2 Sqn SAAF were each instructed to rotate their flights through $\mathrm{K}-13$ as follows:

a. One flight of four aircraft to be dispatched daily from $\mathrm{K}-10$ on an operational mission landing at $\mathrm{K}-13$.

b. The same flight to re-arm and re-fuel at $\mathrm{K}-13$ and fly another two missions from $\mathrm{K}-13$ on the same day.

c. The flight then had to stay the night at $\mathrm{K}-13$.

d. The next day they were to fly one more mission from $\mathrm{K}-13$, after which they were te return to $\mathrm{K}-10 .{ }^{15}$
Twenty ground crew formed the 2 Sqn $R$ and $R$ detachment at K-13. On 7 May 1951 this $R$ and $R$ detachment was moved from $\mathrm{K}-13$ to $\mathrm{K}-16$ where the same rotation procedure as for $\mathrm{K}-13$ was applied to the aircrews. ${ }^{16}$ (Map 1)

In practice the rotation procedure through the forward airfields became far more demanding than the instructions of the original Frag Order had indicated. A typical example is that of a flight consisting of Capt G. Kotze, and Lts A. B. de Wet, I. Gow, M. Frost and F. M. Bekker. Three of these pilots flew 10 successive missions over a period of five days before returning to $\mathrm{K}-10$. The standard of the ground crews' work can be assessed by the fact that the same four aircraft, Nos. 334, 303, 329 and 306 were used on all 10 missions. The operations for the five days flown by the above pilots have been tabulated below in Table 1.

\section{SAAF IN KOREA}

\section{Rotation through the forward airfield K.16: an example}

\begin{tabular}{|c|c|c|c|c|c|c|c|c|}
\hline Serial & $\begin{array}{l}\text { Date } \\
1951\end{array}$ & $\begin{array}{l}\text { Airtield } \\
\text { Up down }\end{array}$ & $\begin{array}{l}\text { Duration } \\
\text { hours }\end{array}$ & $\begin{array}{l}\text { Pilots: Mission } \\
\text { Idr underlined }\end{array}$ & Targets & Armament & Claims & Remarks \\
\hline a & b & $d e$ & i & 9 & h & i & i & k \\
\hline 1 & 13 Nay 1863 & $K-10 K-16$ & 1.40 & $\begin{array}{l}\text { Capt. G. Kotze } \\
\text { Lt. I. Gow } \\
\text { It. A.B. de Wet } \\
\text { Lt. M. Frost }\end{array}$ & $\begin{array}{l}\text { Supply cumps in } \\
\text { Operation Hotpantis }\end{array}$ & $\begin{array}{l}\text { Zxnapalm } \\
6 \times 5^{\prime} \text { HVAR } \\
50 \text { callore }\end{array}$ & $\begin{array}{l}\mathrm{Nil} \\
\text { Bombs jettisoned } \\
\text { Inchon Bay }\end{array}$ & $\begin{array}{l}\text { Target area covered } \\
\text { by bad weather } \\
\text { Crossed bombine. }\end{array}$ \\
\hline 2 & 13 May 1823 & $K-16 K-16$ & & $\begin{array}{l}\text { Capt. G. Kotze } \\
\text { Lt. I. Gow } \\
\text { Lt. A.B. de Wet } \\
\text { Lt. M. Frost }\end{array}$ & $\begin{array}{l}\text { Camoullaged } \\
\text { supply dumps } \\
\text { Operation Hotipanis }\end{array}$ & as above & $\begin{array}{l}\text { Destroyed: } \\
\text { 1x supply dump }\end{array}$ & $\begin{array}{l}\text { Second mission } \\
\text { on } 13 \text { May }\end{array}$ \\
\hline 3 & 14 May 1802 & $K-16 K-16$ & 0.50 & $\begin{array}{l}\text { Capt. G. Kotze } \\
\text { Lt. I. Gow } \\
\text { Lt. A.B. de Wet } \\
\text { Lt. M. Frost }\end{array}$ & $\begin{array}{l}\text { Buildings and } \\
\text { supply stacks } \\
\text { Operation Windoum }\end{array}$ & as above & $\begin{array}{l}\text { Damaged: } \\
\text { 2x buldings } \\
\text { 1x large POL dump }\end{array}$ & \\
\hline 4 & 14 May 1809 & $K=16 K-16$ & 0.55 & $\begin{array}{l}\text { Capt G. Kotze } \\
\text { Lt. I. Gow } \\
\text { Lt. A.B. de Wet } \\
\text { Lt. M. Frost }\end{array}$ & $\begin{array}{l}\text { Camoullaged } \\
\text { suppy y dumps } \\
\text { Operation Windourn }\end{array}$ & as above & $\begin{array}{l}\text { Poor visibi- } \\
\text { ity prevented } \\
\text { assessment }\end{array}$ & $\begin{array}{l}\text { Second Mission } \\
\text { on } 14 \text { May } \\
\text {. }\end{array}$ \\
\hline 5 & 15 May 1807 & K. $16 K-16$ & 1.20 & $\begin{array}{l}\text { Capt. G. Kotze } \\
\text { Lt. F. Bekker } \\
\text { Lt. A.B. de Wet } \\
\text { L.t. M. Frost }\end{array}$ & $\begin{array}{l}\text { Viliage } \\
\text { Caves } \\
\text { Vehicles }\end{array}$ & as above & $\begin{array}{l}\text { Desiroyed: } \\
2 x \text { vehicles } \\
\text { Damaged: } \\
\text { 1x village } \\
\text { 1x POL dump }\end{array}$ & $\begin{array}{l}\text { Bekker replaces } \\
\text { Gow. }\end{array}$ \\
\hline 6 & 15 May 1823 & K-16K-16 & 1.20 & $\begin{array}{l}\text { Capt. G. Kotze } \\
\text { Lt. F. Bekker } \\
\text { Lt. A.B. de Wet } \\
\text { Lt. M. Frost }\end{array}$ & $\begin{array}{l}\text { Village } \\
\text { Vehicle }\end{array}$ & as above & $\begin{array}{l}\text { Destroyed: } \\
\text { 2x vehicles } \\
\text { damaged: } \\
1 \mathrm{x} \text { vehicle } \\
1 \mathrm{x} \text { village }\end{array}$ & $\begin{array}{l}\text { Second viission } \\
\text { on } 15 \text { May. }\end{array}$ \\
\hline
\end{tabular}




\begin{tabular}{|c|c|c|c|c|c|c|c|}
\hline Serial & $\begin{array}{l}\text { Date } \\
1951\end{array}$ & $\begin{array}{l}\text { ssion Aiffield } \\
\text { beer Up down }\end{array}$ & $\begin{array}{l}\text { Duration Pilots: Mission } \\
\text { hours Idr underlined }\end{array}$ & Targets & Armament & Claims & Remarks \\
\hline a & $b$ & $c d e$ & f & h & i & i & k \\
\hline 7 & 16 May 1807 & $K-16 K-16$ & $\begin{array}{l}1.20 \text { Capt. G. Kotze } \\
\text { Lt. F. Bekker } \\
\text { Lt. A.B. de Wet } \\
\text { Lt. M. Frost }\end{array}$ & $\begin{array}{l}\text { Caves } \\
\text { vehicle }\end{array}$ & as above & $\begin{array}{l}\text { Damaged: } \\
\text { 1x vehice }\end{array}$ & \\
\hline 8 & 16 May 1802 & $K-16 K-16$ & $\begin{array}{l}1.35 \text { Capt. G. Kotze } \\
\text { Lt. F. Bekker } \\
\text { Lt. A.B. de Wet } \\
\text { Lt. M. Frost }\end{array}$ & $\begin{array}{l}\text { supply dumps } \\
\text { in wood }\end{array}$ & as above & Fires statted & \\
\hline 9 & 16 May 1815 & $K-16 K-16$ & $\begin{array}{l}1.30 \text { Capt. G. Kotze } \\
\text { Lt. F. Bekker } \\
\text { L. A.B. de Wet } \\
\text { L.. M. Frost }\end{array}$ & $\begin{array}{l}\text { supplies in } \\
\text { dug-out } \\
\text { Highway bridge }\end{array}$ & as above & $\begin{array}{l}\text { Destroyed: } \\
\text { 1x supply dump } \\
\text { Damaged: } \\
\text { 1x Highway bridges }\end{array}$ & $\begin{array}{l}\text { Third Mission } \\
\text { on } 16 \text { May. }\end{array}$ \\
\hline 10 & 17 May 1802 & $K-16 K-10$ & $\begin{array}{l}2.00 \text { Capt. G. Kotze } \\
\text { Lt. F. Bekker } \\
\text { Lt. A.B. de Wet } \\
\text { L. M. Frost }\end{array}$ & Village & as above & $\begin{array}{l}\text { Poor visibil. } \\
\text { ity prevented } \\
\text { assessment }\end{array}$ & $\begin{array}{l}\text { Last mission of } \\
\text { rotation through } \\
K-16-\text { returned } \\
\text { to } \mathrm{K}-10\end{array}$ \\
\hline
\end{tabular}

Source: SAAF220: Debriefing Forms, 13 - 17 May 1951.

\section{Sinuiju Raid}

The routine of the interdiction missions was broken on 9 May 1951, when 312 aircraft of the 5th Air Force and the 1st Marine Air Wing participated in Operation Buster, a massive raid on the $26 \mathrm{~km}^{2}$ Sinuiju airfield area, which was a major North Korean airbase just south of the Yalu River. This and other airfields in North Korea had reached a stage of repair where they could be used in a CCAF attempt to gain air superiority over North Korea, with the possibility of backing a future Communist ground offensive with air support. The neutralization of these airfields was thus vital. In this major raid there were four distinct tasks: a. the provision of top cover to protect the attacking fighter-bombers from interference from MIG-15's (Sinuiju was very close to the MIG bases in Manchuria), b. flak suppression, c. the actual bombing of the airstrip and the surrounding revetments and supply dumps, and d. the rescue effort by SA-16 and SA-17 flying boats escorted by tactical aircraft. ${ }^{17}$ These tasks were allocated as follows:
a. Top cover:
- 4 Wing F-86 Sabres
- 27 Wing F-84 Thun- derjets
- 1st Marine Air Wing Pantherjets
b. Flak suppression: - 8 Wing F-80 Shooting

- 49 Wing F-80 Shoot-

ing Stars

- 51Wing F-80 Shooting

Stars

c. Attack on airfield: - 1st Marine Air Wing

Corsairs

- 18 Wing F-51 Mustangs $^{18}$

d. Rescue escort: -18 Wing F-51 Mustangs (16 aircraft from 2 Sqn, eight aircraft from 18 FighterBomber Group.)

The co-ordination of the successive waves of aircraft on their various interrelated tasks required precise direction and timing. The 18 FighterBomber Wing Frag Order for 9 May 1951 (dated: 8 May 1951) tasked 2 Sqn as follows:

'Dispatch 1, 24 ship flt (including 8 from 18th) to perform escort and rescue cap for SA-16's and SA-17's as indicated below.' ${ }^{19}$

The RV time was given as $12 \mathrm{~h} 45$ and the RV point as XC5005. The orbit time was to be from $13 \mathrm{~h} 00$ to $16 \mathrm{h00}$ and the orbit point XC3062. (Map 1)20 The attack itself started at $14 \mathrm{~h} 00 .{ }^{21}$ Any of the attacking pilots who got into trouble were to head for the orbit area where they could ditch and be picked up by the flying boats. The task of 2 Sqn was to fly combat air patrol (CAP) over the 
downed pilots and the rescue aircraft.

In fulfilment of this mission, 162 Sqn aircraft in four flights of four aircraft each took off; starting at 11 h10 with Maj. J. P. D. Blaauw as leader, using the appropriate call sign of 'Ashcake Buster Leader'. They completed their mission without incident. ${ }^{22}$ The raid itself was a great success. Besides hitting a number of aircraft on the ground the fighter-bombers destroyed 106 buildings, one large aviation fuel dump, and 26 ammunition and supply dumps. They also inflicted heavy casualties on enemy personnel. All this was achieved at the cost of one Thunderjet damaged. ${ }^{23}$

\section{Reduced Sortie Rate}

From 22 May 19512 Sqn sorties were limited to 16 per day. The proximity of $\mathrm{K}-16$ to the MLR allowed for sorties of a much shorter duration with a resultant increased sortie rate. The danger had developed that too many experienced pilots might complete their operational tours of 75 sorties before the end of the month, leaving no one to train and lead the new batch of replacement pilots expected at that time.$^{24}$ This policy as well as the adverse weather kept the daily sortie rate at 16 and even below, with only a few exceptions, until 8 June 1951 when 17 replacement pilots became available for operational sorties on completion of their training. The 17 pilots had arrived in two batches: one of 11 pilots under Capt. H. J. Snyman on 29 May, and another of six pilots under Capt. R. H. Rogers on 1 June $1951 .{ }^{25}$ In addition Capt. L. P. T. Eager and four additional pilots arrived on 2 June 1951. ${ }^{26}$

Although the sortie rate was reduced for a time the hard work for both pilots and ground crew continued, and after 8 June 1951 the sortie rate rose to approximately 24 sorties per day. The men who had prepared the new batch of pilots for combat now gradually completed their tours. On 21 June 1951 Capt J. A. Joubert led four aircraft from $\mathrm{K}-16$ on a road interdiction mission to complete his 100th effective combat sortie in Korea. This mission effected two complete road cuts in the Chinnampo area with 500lb bombs, and then proceeded to rocket and strafe buildings which had been indicated as secondary targets in the same area. (Map 3) Capt G. G. Willers and Lt P. J. Strydom also completed their tours with 75 sorties each on the same mission. ${ }^{27}$

\section{Marshall's DFC}

One of the most effective missions of the period was one led by Lt $G$. $H$. Marshall on 24 June 1951. Together with Capt L. P. T. Eager, 2/Lts J. F. G. Howe and J. P. Verster he was briefed to carry out an interdiction mission north-east of Kaesong. They carried napalm, rockets and .50 ammunition. They took-off at $19 \mathrm{~h} 45$ and were en route to their target when they heard the airborne controller 'Mosquito Jefferson' call for support from any flight that could hear him. Lt Marshall diverted his flight in answer to the call and the controller indicated the target. It was a concentration of enemy troops about $30 \mathrm{~km}$ south-west of Chorwon. (Map 1) The enemy were defending themselves with automatic weapons, and $20 \mathrm{~mm}$ and $40 \mathrm{~mm}$ anti-aircraft guns. The four Mustangs of 2 Sqn attacked through an intense and accurate barrage of enemy fire. So intense was the enemy fire that the controller instructed a USAF flight to stand-by to CAP any of the South Africans who might be hit. 2/Lts Howe and Verster later expressed surprise at having survived the attack. In spite of this opposition the attack was successful, with the enemy sustaining the following losses: one $40 \mathrm{~mm}$ gun position, two automatic weapons positions and an unknown number of enemy troops destroyed; one $40 \mathrm{~mm}$ gun position damaged. ${ }^{28}$

On 2 July 1951 the courage of these pilots was recognised when the Squadron received notification of the immediate award of the American Distinguished Flying Cross to Lt Marshall and the Air Medal to the other three pilots. ${ }^{29}$ Tragically $2 / \mathrm{Lt}$ Verster was never to hear of his award as he had been killed the previous day ferrying a Mustang from K-10 to K-16. ${ }^{30}$ The citation which accompanied the award to Lt Marshall further described the incident:

'Despite poor visibility and in the face of withering enemy ground fire, Lieutenant Marshall, without hesitation and with complete disregard for personal safety made successive hazardous attacks with relentless accuracy on the enemy positions. In an exceptional display of aggressiveness and aeronautical skill he engineered the attacks of his flight with such outstanding airmanship that the optimum damage was inflicted against the enemy without the loss of one of his aircraft. ${ }^{13}$

\section{Airfield Neutralization}

Aerial photographs taken on 6 June 1951 showed all the North Korean airfields to be unserviceable, but a few days of bad weather gave the Communist time to catch up with the damage 
caused by the FEAF raids. At least one airfield, Sariwon, became operational for light aircraft. On 14 June the CCAF started with a particular type of harassment which had been successfully used by the Russians against the Germans during World War II. PO-2 Polikarpov biplanes, canvas covered open cockpit trainers, were sent late at night or early in the morning to catch 5th Air Force aircraft being prepared by groundcrews for the coming day's missions. The damage that could be inflicted by these small lone-flying aircraft was relatively slight, but their nuisance value was considerable. They were nicknamed 'Bed Check Charlies' by 5th Air Force personnel. In the early hours of 14 June 1951 two PO-2's headed southwards. One bombed a runway repair crew at Suwon Airbase (K-13) and another an Eighth Army vehicle park near Inchon ${ }^{32}$ This was hardly effective close air support, but it was a beginning.

K-16 airfield was situated on an island in the Han River just south of Seoul. It was also vulnerable to attack. On 16 May 1951 the Squadron diarist indicated the proximity of this forward airfield to the MLR by mentioning that flashes of friendly artillery could be seen from the airfield. ${ }^{33}$ During the night of 15-16 June 1951 the SAAF ground personnel experienced their first enemy attack when $\mathrm{K}-16$ was bombed and strafed. No damage or casualties were reported. ${ }^{34}$ During the next few days increased enemy air activity became evident as the CCAF attempted to implement the revised air war plan of 10 May 1951. On 17 June 19514 Wing Sabres encountered 25 MIG-15's, whose pilots were more aggressive than had been previously experienced. Large numbers of MIG-15's again challenged the Sabres on 18 and 19 of June 1951. On 20 June 1951 a flight of Mustangs from 18 Fighter Bomber Wing were sweeping a road south of Sinuiju when they encountered eight IL-10's (Ilyushin ground attack aircraft) en route to render close support to the CCF ground forces on the island of Sinmi-do. Both sides called for reinforcements and a dogfight ensued involving in addition to the original Mustangs and IL-10's, Yak-9's, MIG-15's and Sabres. The 5th Air Force lost one Mustang in exchange for one Yak-9 destroyed, two IL-10's destroyed and three damaged, and four MIG-15's damaged. ${ }^{35}$

The FEAF commanders decided to meet the mounting Communist air threat with an intensive airfield neutralization programme. Commencing on 17 June 1951, B-26's attacked the North Korean airfields at night, while B-29's and the fighter-bombers attacked during the day. ${ }^{36} \mathrm{~A}$ decisive stage of the war had been reached, both on the ground and in the air. 2 Squadron became involved in the airfield raids. On 18 June 1951, one flight of SAAF aircraft bombed a suspected airstrip at Ongjin with 500lb bombs causing five craters on what was thought to be the runway. ${ }^{37}$ On 19 June 1951 a similar raid accounted for four direct hits on the runway of the Haeju airfield. On 23 June 1951, Capt J. Swanepoel led Lts D. Green, S. de la Harpe and T. Sivertsen on an attack against the revetments at Sariwon airfield, which was protected by 37 automatic weapons and numerous $20 \mathrm{~mm}$ and $40 \mathrm{~mm}$ anti-aircraft guns. Capt Swanepoel led his flight in at 6-15 metres above the ground and succeeded in covering the target with napalm. Due to the intense and accurate enemy fire they did not wait around to survey the damage. The same day separate flights of four aircraft each from 2 Sqn attacked the airfields at Anak. Sinmak and Ongjin. ${ }^{38}$ On 24 June 1951 flights of four aircraft from 2 Sqn attacked the airfields at Sariwon, Anak, Sinmak and Haeju using V.T. fused rockets for flak suppression and 500lb bombs to pothole the runways. ${ }^{39}$ Thus, as the ground offensive came to and end the air offensive moved into top gear. With the commencement of the FEAF airfield neutralization programme the Communists began to make their peace overtures. (Map 1)

\section{The Cost}

The going for the UN pilots was not always easy. The Communists were determined to protect their supply routes, supply dumps and airfields from air attack; and besides excellent camouflage techniques, they also employed a heavy anti-aircraft screen. In May 1951 FEAF intelligence officers plotted the positions of 252 anti-aircraft guns and 673 automatic weapons. The anti-aircraft gun positions were fixed, but the danger along the main supply routes was truck-towed $37 \mathrm{~mm}$ Soviet M-1939 automatic weapons. These were effective against targets up to $1400 \mathrm{~m},{ }^{40}$ and were to take their toll on 2 Sqn. Between 22 April 1951 and 24 June 1951, 2 Sqn lost five aircraft as a direct result of enemy ground fire and three to accidents. A further eight were damaged by enemy action. Pilot casualties amounted to three killed (two in accidents) and four wounded. One pilot listed as missing in action was later found to have fallen into enemy hands. The Mustang's liquid cooled engine made it particularly vulnerable to ground fire. This factor, together with the addition to each Communist Chinese regiment of an air defence company armed with Soviet 
$12,7 \mathrm{~mm}$ machine guns which were very effective against low-flying aircraft, increased the operational hazard. ${ }^{41}$

Test flights against own forces anti-aircraft batteries revealed the extreme vulnerability of the wingman in the two aircraft low-level element, which searched for targets which the enemy concealed with increasing skill. After this test the 18 Fighter-Bomber Wing, including 2 Squadron, changed its armed recce tactics in an effort to avoid further losses. In the new method of armed recce, only the flight leader flew at $100 \mathrm{~m}$ looking for targets of opportunity, while the remaining three aircraft covered him for flak from $1200 \mathrm{~m}^{42}$

On 29 April 1951 Capt Kotze's aircraft was hit in the engine by automatic fire while attacking enemy troops dug in along a ridge north of Seoul. His leader, Lt I. Gow, strafed and silenced the gun position receiving a bullet in the wing in the process. ${ }^{43}$ On 30 April 1951, Lt P. Celliers led four aircraft on a bombing mission against a railway tunnel on the line between Sinmak and Kumchon. Taking off from $\mathrm{K}-10$ at $08 \mathrm{~h} 40$ they bombed the tunnel with $500 \mathrm{lb}$ G.P. bombs and then split up into two elements to search for secondary targets. At $10 \mathrm{~h} 15$ Lt Celliers' aircraft was hit by anti-aircraft fire about $20 \mathrm{~km}$ to the east of the original target. He baled out of the burning aircraft almost immediately. His wingman, Lt G. G. Paterson, alerted rescue and also re-assembled the original flight, leading it and another 2 Sqn flight to CAP Lt Celliers until he was rescued by helicopter. Lt Celliers finally arrived back at K-10 at $21 \mathrm{~h} 00$ with his right calf badly lacerated by a $20 \mathrm{~mm}$ shell. ${ }^{44}$

On 1 May 1951, the aircraft of Lt D. W. McKellar and Lt G. H. Marshall were hit by automatic weapon fire in the wing tanks while on an interdiction mission. ${ }^{45}$ The next day Capt J. M. Sweeney had a disconcerting experience. While attacking vehicles $5 \mathrm{~km}$ south-east of Songsanni, he was met by intense and accurate automatic ground fire. His aircraft was hit in the port aileron trimming and the starboard side of the cockpit. A bullet lacerated his right buttock. Shepherded by Maj J. P. D. Blaauw and weak from loss of blood, he managed to bring his aircraft back to $\mathrm{K}-16$ where he passed out on landing. When he was brought back to $\mathrm{K}-10$ by $\mathrm{C}-47$, the Medical Officer grounded him for six months. ${ }^{46}$

On 6 May 1951, the day before he completed his tour of duty with 75 sorties, Lt J. H. Kruger's aircraft was hit in the tailplane. On 11 May 1951 his namesake, Lt V. R. Kruger, was involved in an incident while on his 74 th combat sortie. At $15 \mathrm{~h} 30$ Maj J. P. D. Blaauw, Lt P. Clulow, Lt M. Mentz and Lt V. R. Kruger took-off from K-16 on their third mission of the day. At $16 \mathrm{~h} 40,12 \mathrm{~km}$ west of Singye Lt V. R. Kruger's aircraft was hit in the mainplane by enemy ground fire. The wing collapsed and the aircraft caught fire, forcing him to bale out. Maj. Blaauw and Lt Mentz flew a CAP over the downed pilot while Lt Clulow made a vain attempt to alert rescue. When fuel began to run low Maj. Blaauw sent Lts Clulow and Mentz back to $\mathrm{K}-16$ while he continued the CAP until his fuel ran out at $18 \mathrm{~h} 45$. Just before he ran out of fuel, another 2 Sqn flight that had been diverted from an interdiction mission arrived on the scene. Maj. Blaauw belly landed next to Lt Kruger. At the same time Lt Mentz was taking off on his fourth sortie of the day, this time to lead a flight of 3 USAF Mustangs to Lt Kruger's rescue. The two pilots on the ground were successfully lifted by helicopter at 19h45. Lt Kruger had sustained the following injuries: dislocation of the right shoulder, crack of the right scapula, second degree burns of the right hand and fingers and abrasions and second degree burns of the left hand and face. The Squadron Medical Officer declared him unfit to fly for six months. Maj Blaauw was only lightly injured with abrasions and bruises to the nose and eyes and was put off flying for 14 days ${ }^{48}$

On 15 May 1951 at 18h55, Lt M. H. Rorke in No. 2 position in a four aircraft flight crashed on take-off. It was Lt Rorke's third mission of the day; he had previously taken off at $14 \mathrm{~h} 50$ and again at $16 \mathrm{~h} 30$ on interdiction missions. The fatal third mission was also an interdiction mission and the aircraft was loaded with napalm, rockets and .50 ammunition. The aircraft swung through $180^{\circ}$ before colliding with a crashed B-29 bomber at the end of the runway. The heavily loaded F-51 immediately burst into flames. ${ }^{49}$ On 24 May 1951 , Lt A. Gotze's aircraft was hit in the scoop while he was searching for a downed pilot, but he landed safely after being escorted to $\mathrm{K}-18{ }^{50}$ On 1 June 1951, Lt A. Gotze was leading a flight of four aircraft on a low-level recce at about $15 \mathrm{~m}$, when a pilot who could not be immediately identified since he did not use his call sign, was heard to say that his aircraft was burning and that he was baling out. The flight leader then noticed that his No. 2, Lt H. McDonald was missing. A 30 minute search revealed the wreckage of an aircraft which could not be identified, spread over about $180 \mathrm{~m}$ and across a railway line $12 \mathrm{~km}$ south of Pyonggang. There was no sign of the pilot. Lt McDonald was listed as M.I.A. ${ }^{51}$ He was not heard 
Scientia Miliaria, South African Journal of Military Studies, Vol 10, Nr 4, 1980. http://scientiamilitaria.journals.ac.za

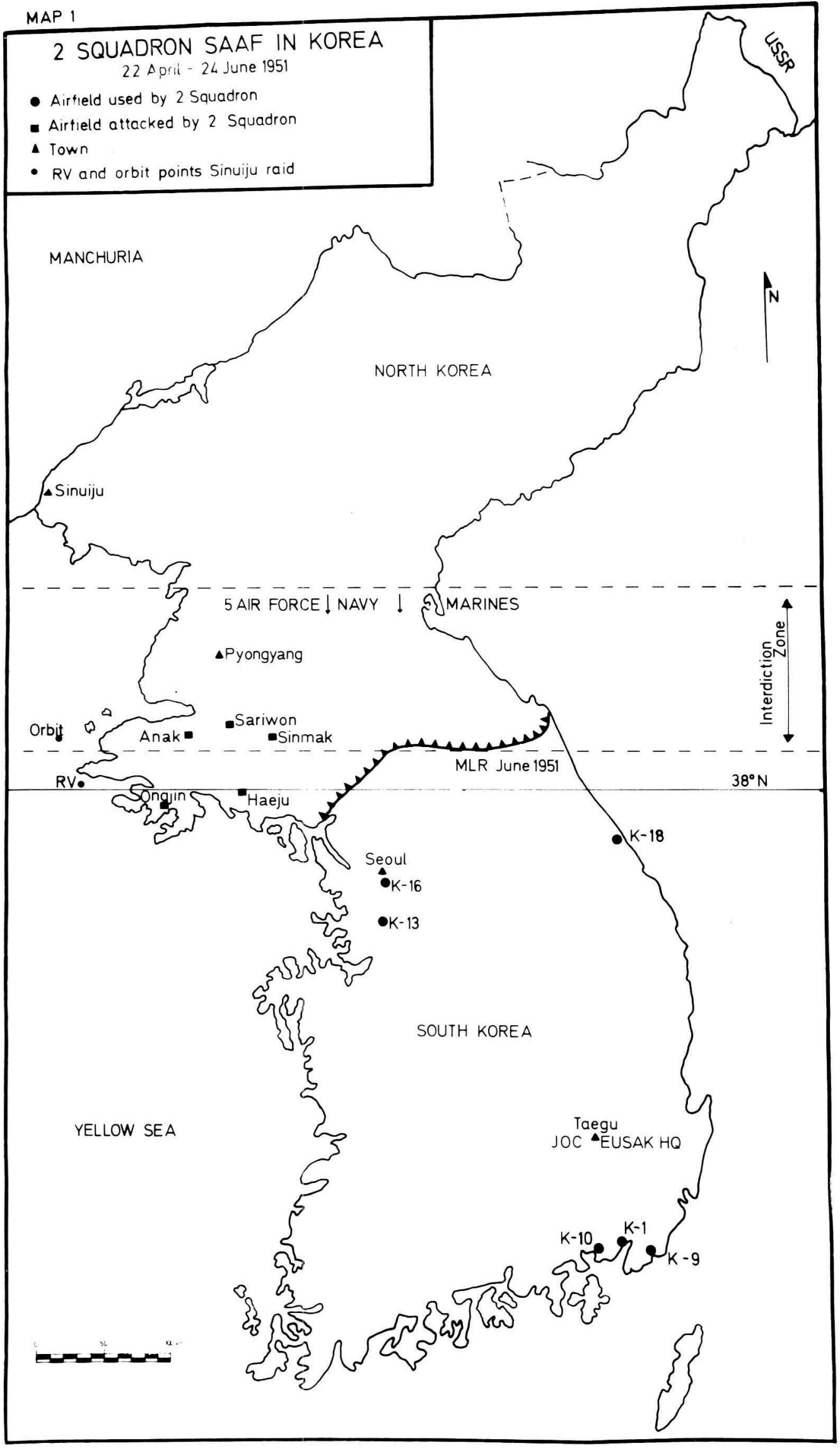

2 Squadron SAAF in Korea 22 April - 24 June 1951

31 
of again until a Voice of India broadcast picked up by chance in Usakos, South West Africa, reported his arrival in a Communist P.O.W. camp. ${ }^{52}$

On 2 June 1951, two aircraft were damaged when two pilots in training, 2/Lts $T$. Liebenberg and R. $V$. Sherwood suffered mishaps on landing at $\mathrm{K}-10 .{ }^{53}$ These incidents were attributed to the unsuitability of $\mathrm{K}-10$ airfield for the transitional training of relatively inexperienced pilots. After this, authority was sought and received from the Officer Commanding 18 Fighter-Bomber Wing for transitional training to take place at the nearby $\mathrm{K}-1$ airfield, which was considered to be far more suitable ${ }^{54}$ On 9 June 1951, 2/Lt T. Liebenberg, in No. 4 position on a flight led by Lt F. M. Bekker and carrying a load of $500 \mathrm{lb}$ bombs, rockets and .50 ammunition, crashed in flames on take-off. The aircraft was a total wreck and the pilot killed.55 Lt F. M. Bekker was again involved in an incident on 13 June 1951 while on an early morning interdiction mission. His aircraft was hit in the starboard mainplane wing root by an explosive bullet. He had to land at $\mathrm{K}-16$ without brakes as the bullet had severed an hydraulic pipe. ${ }^{56}$

The final casualty of the period occurred on 22 June 1951. At 10 h55 Lt A. G. Frisby led a flight consisting of Lt D. Marchand, Cmdt R. F. Armstrong and Lt $\dot{C}$. de Jongh from $\mathrm{K}-16$ on a mission to interdict supplies north-west of Namchonjam. West of Sibyonni, at $600 \mathrm{~m}$ the leader called that he had been hit by ground fire and that he was baling out. At $250 \mathrm{~m}$ a brown object was seen to leave the aircraft, which then crashed into the side of a river bed and broke up. No parachute was seen and there was no sign of the pilot. At $15 \mathrm{~h} 00 \mathrm{Cmdt}$ Armstrong led four aircraft on a further search of the scene but still no sign was found of the pilot. They concluded that he had, in fact, baled out at $250 \mathrm{~m}$, but that his parachute had failed to open. ${ }^{57}$

\section{Conclusion}

2 Squadron's main objective at this time was the isolation of the battlefield from the enemy sources of supply. The main threat came from enemy ground fire. In the face of this threat the South African pilots displayed a calm professionalism hallmarked by a high level of mutual loyalty and team spirit, as demonstrated by the manner in which the Squadron OC Cmdt R. F. Armstrong, the $2 \mathrm{I} / \mathrm{C}$ Maj J. P. D. Blaauw and Lt M. Mentz exposed themselves to considerable danger in order to assist comrades in difficulties. The general effort of the Squadron showed precision, persistence and courage in carrying out their task, with pilots frequently flying three and even four missions in one day. The efficiency attained by 2 Squadron enabled its officers and men to make a significant contribution to the FEAF effort during this critical period.

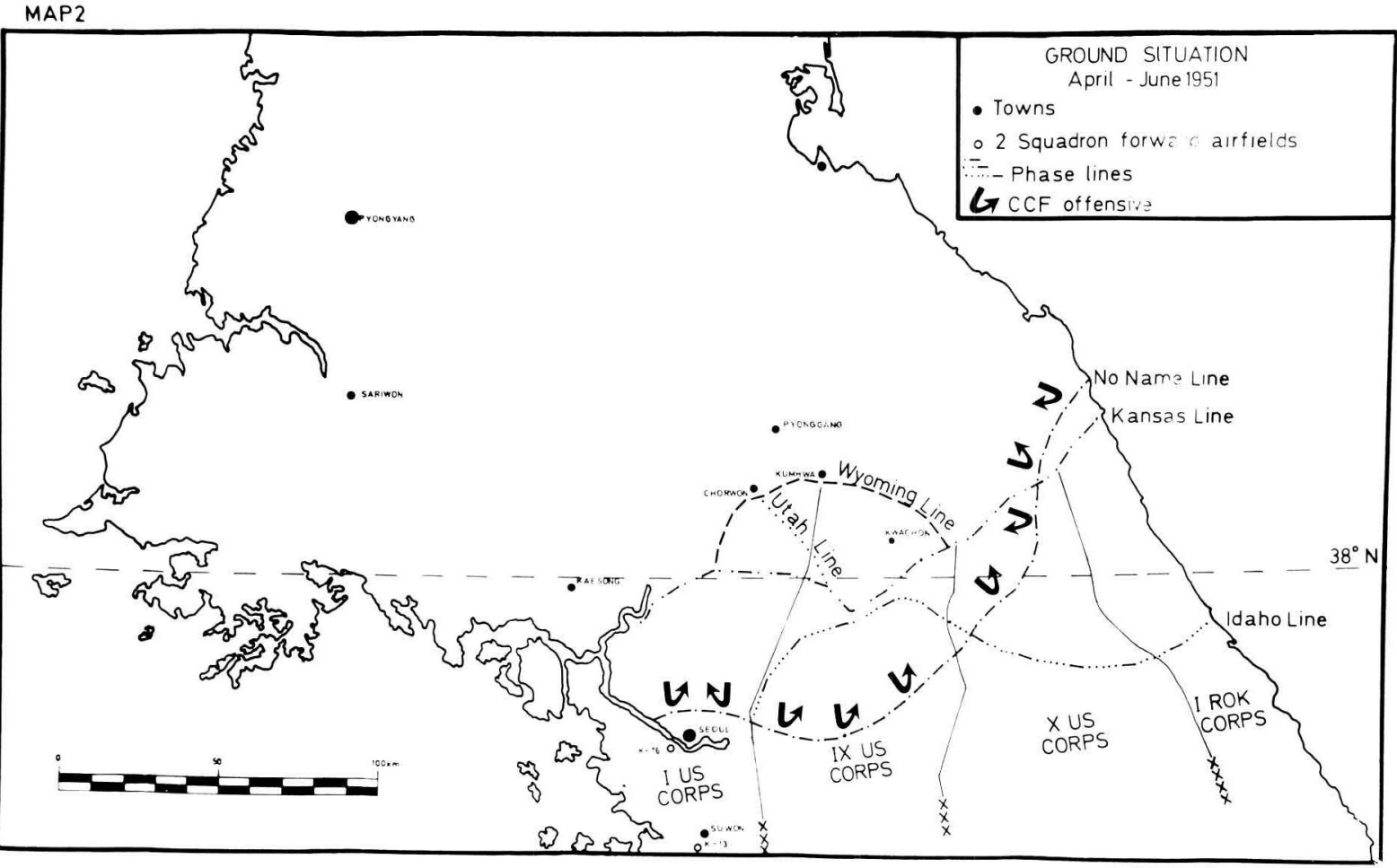

Ground situation April - June 1951 


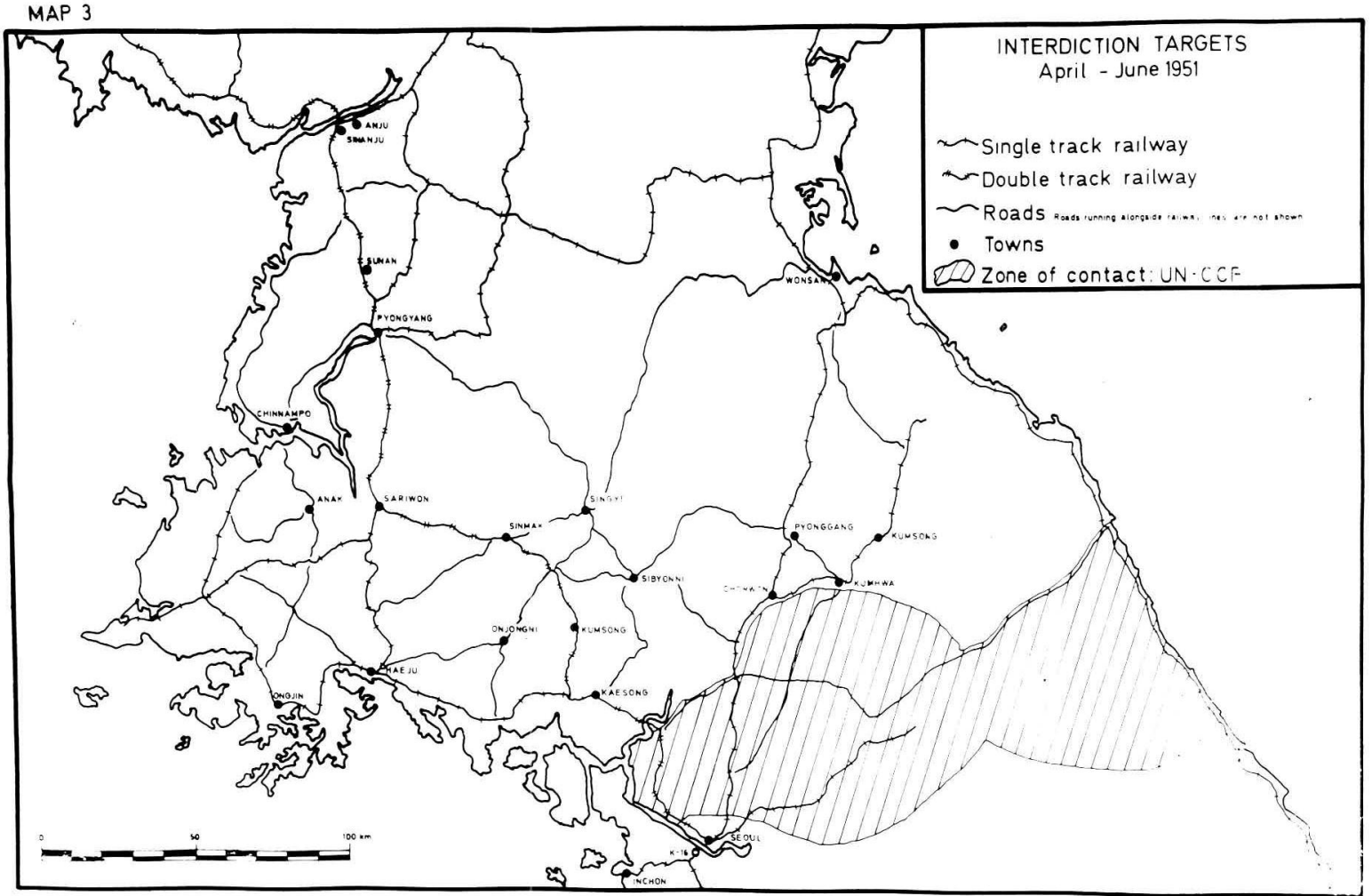

Interdiction Targets April - June 1951

\section{FOOTNOTE}

* Mr Dermot Michael Moore, MA (History) is a senior Lecturer of History at the University of Fort Hare and he is also a Major in the SAIC (Comdos). He is currently doing research on the SAAF in Korea for a D Litt et Phil Degree at Unisa.

\section{References}

1. J. W. Pratt, A History of United States Foreign Policy, 2nd edition, Englewood Cliffs: Prentice-Hall, 1965, p. 490

2. J. Miller, O. J. Carroll \& M. E. Tackley, Korea 1951-1953, Washington: Office of the Chief of Military History, (s.a.), pp. 20-27.

3. Ibid., p. 103

4. Ibid., pp. 102-107

5. Ibid., p. 109

6. Ibid., pp. 110-111.

7. D. Rees, Korea: The Limited War, London: Macmillan, 1964, p. 376.

8. R. F. Futrell, L. S. Moseley \& A. F. Simpson, The United States Air Force in Korea 1950-1953, New York: Duell, Sloan \& Pearce, 1961, pp. 278-279.

9. War Diaries and Missions SAAF (Korea), Box 14, Debriefing Forms SAAF220: 22 April 1951-30 April 1951; Box 15, Debriefing Forms SAAF220: 1 May 1951-31 May 1951; Box 16, Debriefing Forms SAAF220, 1 June 1951-24 June 1951.

10. Futrell, et al. The United States Air Force in Korea, p. 331; Republic of Korea, The History of the United Nations Forces in the Korean War, Vol. 1, Seoul, 1972, p. 422.

11. War Diaries and Missions SAAF (Korea), Box 4, 2 Squadron War Diary, 23 April 1951.

12. War Diaries and Missions SAAF (Korea), Box 3, 2 Squadron War Diary, 25 March 1951.

13. War Diaries and Missions SAAF (Korea), Box 4, 2 Squadron War Diary, 24 April 1951.

14. War Diaries and Missions SAAF (Korea), Box 4, 2 Squadron War Diary, Appendix "|", Frag Order 5-2 for 2 May 1951.

15. War Diaries and Missions SAAF (Korea), Box 4, 2 Squadron War Diary, Appendix "l", Frag Order 5-2 for 2 May 1951.
16. War Diaries and Missions SAAF (Korea), Box 4, 2 Squadron War Diary, 7 May 1951

17. Futrell, et al., The United States Air Force in Korea, p. 277 Republic of Korea, The History of the United Nations Forces in the Korean War, Vol. 1, p. 418.

18. Futrell, et al., The United States Air Force in Korea, p. 277.

19. War Diaries and Missions SAAF (Korea), Box 4, 2 Squadron War Diary, Appendix "I", Frag Order 5-9 for 9 May 1951.

20. War Diaries and Missions SAAF (Korea), Box 4, 2 Squadron War Diary, Appendix "I", Frag Order 5-9 for 9 May 1951.

21. Futrell, et al., The United States Air Force in Korea, p. 277.

22. War Diaries and Missions SAAF (Korea), Box 4, 2 Squadron War Diary, 9 May 1951; Box 15, Debriefing Forms SAAF220, 9 May 1951.

23. Futrell et al., The United States Air Force in Korea, p. 277.

24. War Diaries and Missions SAAF (Korea), Box 4, 2 Squadron War Diary, 22 May 1951.

25. War Diaries and Missions SAAF (Korea), Box 4, 2 Squadron War Diary, 29 May 1951, 1 June 1951, 8 June 1951.

26. War Diaries and Missions SAAF (Korea), Box 4, 2 Squadron War Diary, 2 June 1951

27. War Diaries and Missions SAAF (Korea), Box 4, 2 Squadron War Diary, 21 June 1951; Box 16, Debriefing Forms SAAF220: 21 June 1951

28. War Diaries and Missions SAAF (Korea), Box 4, 2 Squadron War Diary, 24 June 1951; Box 16, Debriefing Forms SAAF220: 24 June 1951

29. War Diaries and Missions SAAF (Korea), Box 5, 2 Squadron War Diary, 2 July 1951.

30. War Diaries and Missions SAAF (Korea), Box 5, 2 Squadron War Diary, 1-2 July 1951.

31. War Diaries and Missions SAAF (Korea), Box 5, 2 Squadron War Diary, July 1951 Appendix " $A$ ": Citation for the immediate award of the Distinguished Flying Cross to Lt. G. H. Marshall.

32. Futrell et al., The United States Air Force in Korea, p. 280.

33. War Diaries and Missions SAAF (Korea), Box 4, 2 Squadron War Diary, 22 May 1951.

34. War Diaries and Missions SAAF (Korea), Box 4, 2 Squadron War Diary, 16 June 1951.

35. War Diaries and Missions SAAF (Korea), Box 4, 2 Squadron War Diary, 20 June 1951; Futrell et al., The United States Air Force in Korea, pp. 280-281. 
36. Futrell et al., The United Siates Air Force in Korea, pp. 281-282

37. War Diaries and Missions SAAF (Korea), Box 4, 2 Squadron War Diary, 18 June 1951; Box 16, Debriefing Forms SAAF220: 18 June 1951.

38. War Diaries and Missions SAAF (Korea), Box 4, 2 Squadron War Diary, 23 June 1951; Box 16, Debriefing Forms SAAF220: 23 June 1951

39. War Diaries and Missions SAAF (Korea), Box 4, 2 Squadron War Diary, 24 June 1951; Box 16, Debriefing Forms SAAF220: 24 June 1951.

40. Futrell et al., The United States Air Force in Korea, p. 307.

41. Ibid., p. 306

42. Ibid., p. 306; Republic of Korea, The History of the United Nations Forces in the Korean War, Vol. 1, p. 421.

43. War Diaries and Missions SAAF (Korea), Box 14, Debriefing Forms SAAF220: 29 April 1951.

44. War Diaries and Missions SAAF (Korea), Box 4, 2 Squadron War Diary, 30 April 1951; Box 14, Debriefing Forms SAAF220: 30 April 1951

45. War Diaries and Missions SAAF (Korea), Box 15, Debriefing Forms SAAF220: 1 May 1951.

46. War Diaries and Missions SAAF (Korea), Box 4, 2 Squadron War Diary, 2 May 1951; Box 15, Debriefing Forms SAAF220: 2 May 1951.

47. War Diaries and Missions SAAF (Korea), Box 4, 2 Squadron War Diary, 6-7 May 1951.
48. War Diaries and Missions SAAF (Korea), Box 4, 2 Squadron War Diary, 11 May 1951; Box 15, Debriefing Forms SAAF220; 11 May 1951; Republic of Korea, The History of the United Nations Forces in the Korean War, Vol. 1, p. 420

49. War Diaries and Missions SAAF (Korea), Box 4, 2 Squadron War Diary, 15 May 1951; Box 15, Debriefing Forms SAAF220: 15 May

50. War Diaries and Missions SAAF (Korea), Box 15, Debriefing Forms SAAF220: 24 May 1951.

51. War Diaries and Missions SAAF (Korea), Box 4, 2 Squadron War Diary, 1 June 1951; Box 16, Debriefing Forms SAAF220: 1 June 1951.

52. H. Parker, Out of the Sky into the Bag, Outspan, Vol. 51, No. 1352. p. 24.

53. War Diaries and Missions SAAF (Korea), Box 4, 2 Squadron War Diary, 2 June 1951

54. War Diaries and Missions SAAF (Korea), Box 4, 2 Squadron War Diary, 8 \& 18 June 1951

55. War Diaries and Missions SAAF (Korea), Box 4, 2 Squadron War Diary, 9 June 1951; Box 16, Debriefing Forms SAAF220: 9 June 1951.

56. War Diaries and Missions SAAF (Korea), Box 16, Debriefing Forms SAAF220: 13 June 1951.

57. War Diaries and Missions SAAF (Korea), Box 4, 2 Squadron War Diary, 22 June 1951; Box 16, Debriefing Forms SAAF220: 22 June 1951. 